\title{
PROFITABILITAS TERHADAP RETURN SAHAM
}

\author{
Happy Sista Devy \\ Institut Agama Islam Negeri Pekalongan \\ hsista14@gmail.com
}

\begin{abstract}
The development of the capital market is currently followed by the development of the stock market is increasingly in demand by investors as well, seen from data on Indonesia Stock Exchange (IDX) which shows that the stocks included in the sharia has increased. An investor will do the analysis to make an investment decision. The analysis is technical and fundamental. One of the fundamental analysis is profitability ratio analysis issued by the company. Good financial performance will be the information used as a positive signal by investors, because companies that have good financial performance will provide more benefits for investors. The purpose of this research is to examine and analyze profitability variables on stock returns in Jakarta Islamic Index (JII) period 2012-2016. Population of this research is a company included in the Jakarta Islamic Index (JII). This research using sample criteria, we obtained a sample of 21 companies included in the Jakarta Islamic Index (JII) for the period of 2012-2016 and published annual financial report data on Indonesia Stock Exchange (IDX) required during the study. The variables used in this research are earning per share (EPS), return on equity (ROE), return on asset (ROA), return on sales (ROS), return on investment (ROI), size as control variable, and stock return as the dependent variable. Result of this research show that investor on Jakarta Islamic Index (JII) see simultaneously the profitability ratio as a signal for investment decision making. Variable size can be used as control variable in that used in this research. Profitability ratios that are taken by investors are return on assets (ROA), earnings per share (EPS), and return on investment $(R O I)$. So that should be a special attention for companies incorporated in the Jakarta Islamic Index (JII) to increase investor interest to invest in the company.
\end{abstract}

Keywords : stock return, profitability ratio, size.

\section{PENDAHULUAN}

Peningkatan efisiensi keuangan dalam suatu negara salah satunya melalui adanya pasar modal (Aryanti, 2016). Adanya pasar modal baikinvestor maupun perusahaan atau emiten sangat dimudahkan oleh sistemnya, sebuah perusahaan go public dapat memberikan informasi-informasi keuangan dan lainnya untuk di publish sehingga para investor dapat dengan mudah mendapat informasi baik keuangan maupun lainnya untuk memilih investasi. Perkembangan pasar modal yang cukup pesat ini diiringi dengan adanya pasar saham syariah yang diyakini menjadi salah satu pilar kekuatan industri pasar modal Indonesia (Soemitra Andri, 2014). Banyaknya emiten syariah yang berkembang memberikan banyak peluang bagi investor untuk berinvestasi pada saham syariah, karena dilihat sebagian besar masyarakat di Indonesia beragama Islam (Aryanti, 2016). Jakarta Islamic Index (JII) merupakan salah satu index yang mengelompokkan 30 saham syariah yang memenuhi kriteria syariah. Tujuan pembentukan Jakarta Islamic Index (JII) adalah untuk meningkatkan kepercayaan investor untuk melakukan investasi pada saham berbasis syariah dan memberikan manfaat bagi pemodal dalam menjalankan 
syariah Islam untuk melakukan investasi di bursa efek.

Seorang investor akan tertarik untuk berinvestasi pada sebuah perusahaan go publik yang memilki kondisi keuangan yang baik. Adanya kondisi keuangan yang baik pada perusahaan mengindikasikan bahwa perusahan tersebut mampu memberikan return yang baik pula pada pemegang saham. Sebuah perusahaan memerlukan adanya investasi penanaman modal dari investor untuk menaikkan harga saham, karena sesuai hukum permintaan bahwa semakin besar permintaan maka akan semakin meningkat pula harga yang ditawarkan. Semakin meningkat harga saham maka semakin meningkat pula return yang dapat diterima oleh investor. Beberapa hal dapat mempengaruhi return saham tersebut, mulai dari analisis teknikal, fundamental dan lain-lain. Salah satu faktor fundamental yang dapat mempengaruhi adalah rasio profitabilitas yang menjadi pertimbangan analisis fundamental pada permintaan saham.

Penilaiain fundamental juga tak lepas dari penilaian pada saham-saham syariah yang ada di Indonesia. Sehingga penilaian kinerja keuangan harus juga diperhatikan pada perusahaan-perusahaan yang tergabung dalam saham-saham syariah. Pada data laporan keuangan tahunan yang dipublikasi oleh perusahaan yang termasuk dalam Jakarta Islamic Index (JII), terlihat nilai rasio-rasio profitabilitas seperti earning per share (EPS), return on equity (ROE), return on asset (ROA), return on invesment (ROI), and Return on Sales (ROS) mengalami fluktuasi selama 2012-2016. Return saham pada saham yang terdaftar di Jakarta Islamic Index (JII) juga mengalami fluktuatif. Peningkatan dan penurunan nilai EPS, ROE, ROA, ROI, dan ROS tersebut tidak seirama dengan adanya peningkatan dan penurunan nilai return saham.

Penelitian yang dilakukan oleh Sikarwar Ekta dan Vijay Kumar Gupta (2016) menunjukkan bahwa earning per share
(EPS), return on equity (ROE), dan return on asset (ROA) mempunyai pengaruh yang positif signifikan. Penelitian tersebut dilakukan dengan populasi saham pada pasar saham di India. Hal yang berbeda ditunjukkan pada hasil penelitian yang dilakukan oleh Nathaniel Nicky (2008), I Dimitrios Maditinos \& Eljko S, et all (2009) dan MadhaviE \& MSV Prasad (2015), adanya EPS, ROE, ROA, dan ROS berpengaruh positif tidak signifikan terhadap return saham. Penelitian menunjukkan bahwa naik turunnya rasio profitabilitas tersebut tidak berpengaruh terhadap naik turunnya nilai return saham. Penelitian sebelumnya yang dilakukan oleh Dimitrios Maditinos, Eljko S, et al (2009) pada Athens Stock Exchange (ASE) menunjukkan bahwa nilai return on investment (ROI) mempunyai pengaruh yang positif signifikan terhadap return saham. Hasil yang sama juga ditunjukkan pada penelitian Ralp Phaliam (2006) bahwa adanya pengumuman nilai return on investment (ROI) membuat para investor tertarik berinvestasi pada sahamsaham yang mempunyai nilai ROI yang meningkat, sehingga peningkatan ROI tersebut dapat berpengaruh secara positif signifikan terhadap return saham.

Setelah memperhatikan penelitianpenelitian yang sebelumnya dilakukan yang digunakan sebagai refrensi menunjukkan adanya perbedaan hasil atau terdapat gap penelitian, dan melihat adanya fenomena gap antara nilai earning per share (EPS), return on equity (ROE), return on asset (ROA), return on invesment (ROI), Return on Sales (ROS) dengan return saham pada saham yang termasuk dalam Jakarta Islamic Index (JII), maka hal tersebut menjadi latar belakang penelitian tentang pengaruh earning per share (EPS), return on equity (ROE), return on asset (ROA), return on invesment (ROI), and Return on Sales (ROS) terhadap return saham.

Objek penelitian ini bertujuan untuk menguji dan menganalisis pengaruh dari earning per share (EPS), return on equity 
$(R O E)$, return on asset $(R O A)$, return on invesment (ROI), and Return on Sales (ROS) terhadap return saham pada sahamsaham yang termasuk dalam Jakarta Islamic Index (JII) tahun 2012-2016.

\section{KAJIAN PUSTAKA}

\section{Signalling Theory}

Teori signalling menggambarkan bahwa sebuah perusahaan dengan kualitas keuangan yang baik akan dengan sengaja memberikan pengumuman mengenai kondisi keuangan perusahaan. Adanya pengumuman mengenai kondisi keuangan perusahaan diharapkan pasar akan merespon dan mampu membedakan mana perusahaan yang mempunyai kualitas baik dan mana perusahaan yang mempunyai kualitas yang buruk. Sinyal yang diberikan oleh perusahaan diharapkan dapat dimanfaatkan pasar dengan baik dan diintrepertasikan dengan baik, sehingga dapat ditiru oleh perusahaan- perusahaan yang mempunyai kualitas buruk (Megginson, 1987).

Komponen dalam teori signalling yang menjadi elemen kuncinya adalah signal, signaller dan penerima signal. Signaller disini adalah insider, manajemen eksekutif dimana memperoleh informasi tentang individual, organisasi, atau produk dimana outsiders tidak menyadari hal itu. Insiders yang memperoleh informasi positif maupun negatif, hal tersebut sebenarnya merupakan informasi yang sangat berfungsi untuk insider termasuk sampai kepada jumlah dan spesifik tentang produk dan jasa mengenai awal laporan penjualan, atau informasi tentang aspek organisasi yang lain seperti sebuah negosiasi dan yang lain. Hal yang paling sederhana dalam pengumuman

informasi, misalnya informasi probadi yang membantu insider dalam membangun persepsi terhadap kualitas sebuah investasi (Taj, A saud, 2016).

Investor atau pelaku pasar harus canggih dalam menginterpretasikan dan menganalisis informasi yang dikeluarkan oleh perusahaan lebih lanjut. Investor harus dapat membedakan antara "lemon" dan "orange", artinya mereka dapat membedakan informasi sebagai sinyal yang bernilai ekonomis dan yang tidak bernilai ekonomis (Jogiyanto, 2005). Investor yang bereaksi akan menginterpretasikan lebih dalam sinyal atau informasi yang diterima agar dapat mengambil keputusan yang tepat dalam investasi. Sehingga dalam pengambilan keputusan dan melakukan reaksi untuk permintaan saham dapat dilakukan dengan tepat.

\section{Profitabilitas}

Profitabilitas merupakan metode pengukuran berbentuk rasio untuk mengukur besaran laba yang dihasilkan pada perusahaan (Maditinos I Dimitros, Zeljko Sevic, etc (2009). Rasio profitabilitas dapat terdiri dari beberapa rasio didalamnya, seperti earning per share (EPS), return on equity $(R O E)$, return on asset (ROA), return on investment (ROI), dll. Rasio profitabilitas sering digunakan dalam laporan keuangan untuk menganalisis fundamental sebuah perusahaan. Rasio profitabilitas sangat penting sebagai salah satu informasi manajemen perusahaan terhadap investor atau pemegang saham perusahaan. Profitabilitas mampu memberikan deskripsi bagaimana kondisi keuangan perusahaan pada periode waktu tertentu. Brigham EF, Gapenski LC, Ehrhardt, (1999) menyatakan bahwa profitabilitas merupakan perwujudan dari hasil kebijakan dan keputusan manajerial terkait dengan manajemen aset dan hutang perusahaan. Sehingga apa yang dihasilkan dalam profitabilitas merupakan aplikasi dari segala kebijakan dan keputusan yang dilakukan pada perusahaan dalam mengatur keuangan perusahaan.

Dalam menjalankan keuangan perusahan diharuskan bahwa semua biaya yang dikeluarkan dari mulai perencanaan hingga penjualan harus lebih kecil dibandingkan dari pendapatan perusahaan, maka perusahaan tersebut dapat dikategorikan sebagai 
perusahaan yang profitable (Monica Violeta,

Sorin Nicole, 2011). Berbagai macam bentuk rasio yang dibentuk untuk memperlihatkan kondisi keuangan perusahaan tersebut profitable atau tidak memudahkan investor dalam menilai kondisi keuangan sebuah perusahaan. Misalnya pada rasio earning per share (EPS), rasio ini menunjukkan seberapa besar perusahaan mampu memberikan earning pada setiap lembar saham yang diinvestasikan. Sehingga investor dapat melihat langsung sebagai bahan pertimbangan metode fundamental dalam menilai sebuah saham. Salah satu rasio proitabilitas lainnya adalah return on equity (ROE) yang mampu memberikan informasi kepada investor atau pemegang saham seberapa besar sebuah perusahaan mampu memberikan laba atas modal sendiri. Rasio lainnya seperti return on investment (ROI) juga penting untuk diberikan oleh pemegang saham dalam laporan keuangan agar dapat memberikan gambaran bahwa perusahaan mampu mengelola laba atas biaya yang harus dikeluarkan.

\section{Return Saham}

Komponen penting dalam menilai sebuah investasi atau menilai secara kinerja keuangan adalah return saham. Return saham mengambarkan besaran pengembalian dari saham yang telat dipilih oleh investor. Nilai return saham didapatkan dari perubahan harga saham yang selalu berubah-ubah atau fluktuatif. Return saham mencerminkan dari kekuatan pasar, yang artinya harga saham bergantung kepada kekuatan penawaran dan permintaan. Sehingga kondisi pasar penawaran saham lebih banyak, dan permintaan lebih sedikit yang yang akan terjadi yaitu penurunan harga saham. Namun hal yang sebaliknya terjadi apabila kondisi penawaran saham lebih sedikit dibandingkan dengan perminataan maka yang akan terjadi yaitu peningkatan harga saham. Permintaan saham ini dipicu oleh beberapa faktor internal perusahaan dan eksternal dari perusahaan. Sehingga segala informasi menjadi sinyal yang berkaitan dengan kondisi perusahaan merupakan hal yang penting untuk investor.

\section{HIPOTESIS}

\section{Pengaruh Earning per Share (EPS) terhadap Return Saham}

Ekta dan Vijay Kumar Gupta (2016) menunjukkan bahwa pengukuran kinerja keuangan dapat dilihat dari nilai earning per share (EPS) yang menggambarkan berapa besar sebuah perusahaan mampu memberikan earning pada setiap lembar saham. Adanya informasi earning per share (EPS) yang tinggi menggambarkan sebuah perusahaan mampu memberikan earning yang besar pula pada investor. Menurut teori signalling bahwa adanya informasi nilai earning per share (EPS) yang meningkat menjadi sinyal yang positif bagi investor untuk menginvestasikan dananya. Peningkatan earning yang dijadikan sinyal oleh perusahaan membuat investor tertarik untuk berinvestasi pada perusahaan tersebut sehingga menimbulkan peningkatan harga saham yang mampu memberikan return yang besar. Hipotesis pertama dalam penelitian ini adalah sebagai berikut:

$\mathrm{H} 1=$ Earning per Share (EPS) berpengaruh positif terhadap return saham.

\section{Pengaruh Return on Equity (ROE) terhadap Return Saham}

Informasi tentang penilaian kinerja keuangan salah satunya memuat adanya return on equity (ROE), dimana ROE merupakan informasi seberapa besar perusahaan mampu menghasilkan laba atas modal saham sendiri yang dimilki oleh perusahaan. Penelitian yang dilakukan oleh Ismail Ishan (2013) dan Dimitrios Maditinos, Eljko S, et al(2009) menunjukkan bahwa meningkatnya return on equity (ROE) akan memberikan pengaruh yang positif dan signifikan terhadap return saham perusahaan. Informasi return on equity (ROE) yang dipublikasikan oleh perusahaan 
atau emiten dijadikan sinyal yang positif sehingga permintaan akan saham perusahaan meningkat, dan menjadikan return saham pada perusahaan juga mengalami peningkatan. Hipotesis kedua dalam penelitian ini adalah sebagai berikut: $\mathrm{H} 2$ = Return on Equity (ROE) berpengaruh positif terhadap return saham

\section{Pengaruh Return on Asset (ROA) terhadap Return Saham}

Return on Asset (ROA) menunjukkan seberapa besar perusahaan dapat menghasilkan return atas aset yang dimiliki. Informasi yang berkaitan dengan keuangan dapat dijadikan sinyal bagi investor. Sinyal ini dapat menjadi menimbulkan reaksi yang positif maupun negatif terhadap pasar. Sikawar dan Gupta (2016) melakukan penelitian yang menunjukkan bahwa adanya peningkatan nilai

return on asset (ROA) berpengaruh positif dan signifikan terhadap return saham. Sinyal yang diterima investor atas informasi kinerja keuangan perusahaan direspon dan dianalisis sehingga menimbulkan reaksi pasar sehingga menimbulkan perbedaan return saham. Sehingga hipotesis pada penelitian ini adalah sebagai berikut :

$\mathrm{H} 3$ = Return on Asset (ROA) berpengaruh positif terhadap return saham

\section{Pengaruh Return on Sales (ROS) terhadap return saham}

Nilai Return on Sales (ROS) menunjukkan besarnya presentase laba yang dihasilkan oleh penjualan. Semakin besar nilai return on sales (ROS), maka kinerja keuangan perusahaan akan semakin profuktif yang berpengaruh pada tingkat kepercayaan investor untuk menanamkan modalnya pada perusahaan (Bastian dan Suharjo, 2006). Informasi nilai ROS yang tinggi menunjukkan bahwa pengelolaan penjualan sebuah perusahaan tersebut baik, sehingga akan memberikan sinyal baik bagi investor. Sinyal yang diterima oleh investor tersebut akan dianalisis lebih dalam untuk pengambilan keputusan. Apabila nilai ROS mengalami peningkatan maka permintaan saham pada perusahaan tersebut juga meningkat akibat reaksi dari pasar. Penelitian yang dilakukan oleh Arabsalehi dan Imam Mahmudi (2012) menunjukkan hasil penelitian bahwa nilai return on sales (ROS) mempunyai pengaruh yang positif dan signifikan terhadap return saham. Maka hipotesis keempat pada penelitian ini adalah sebagai berikut :

$\mathrm{H} 4$ = Return on Sales (ROS) berpengaruh positif terhadap return saham

\section{Pengaruh Return on Investment (ROI) terhadap return saham}

Nilai return on investment (ROI) menunjukkan seberapa besar perusahaan mampu menggunakan modal secara efisien untuk perusahaan sehingga menghasilkan profit yang maksimal. Penelitian yang dilakukan oleh Palliam Ralph (2006) menunjukkan adanya pengaruh yang positif dan signifikan terhadap return saham. Nilai return on investment(ROI)dapatmemberikan sinyal bahwa sebuah perusahaan mampu memberikan profitabilitas dari produk-produk yang dihasilkan oleh perusahaan. Semakin meningkat nilai $\mathrm{ROI}$ maka menggambarkan kondisi keuangan perusahaan semakin baik. Adanya kondisi keuangan perusahaan yang semakin meningkat memberikan sinyal positif kepada investor. Sehingga adanya sinyal tersebut membuat investor tertarik untuk membeli saham perusahaan tersebut. Peningkatan permintaan saham akan mengakibatkan peningkatan return saham pula. Maka hipotesis kelima pada penelitian ini adalah sebagai berikut :

$\mathrm{H} 5=$ Return on Investment (ROI) berpengaruh positif terhadap return saham

\section{Size (variabel kontrol) \\ Pada penelitian ini variabel kontrol yang digunakan adalah size atau ukuran perusahaan. Ukuran perusahaan menunjukkan seberapa besar dari perusahaan yang dilihat dari aset}


Tabel 1

Data Sampel Perusahaan

\begin{tabular}{ll}
\hline Kode Perusahaan & \multicolumn{1}{c}{ Nama Perusahaan } \\
\hline AALI & Astra Agro Lestari Tbk \\
ADRO & Adaro Energi Tbk \\
ASII & Astra International Tbk \\
BMTR & Gobal Mediacom \\
CPIN & Charoen Pokphand Indonesia Tbk \\
ICBP & Indofood CBP Sukses Makmur Tbk \\
INCO & Vale Indonesia Tbk \\
INDF & Indofood Sukses Makmur Tbk \\
INTP & Indocement Tunggal Raya Megah Tbk \\
ITMG & Indo Tambang Raya Megah \\
KLBF & Kalbe Farma Tbk \\
LSIP & PP London Sumatera Indonesia Tbk \\
MNCN & Media Nusantara Citra Tbk \\
MPPA & Matahari Putra Prima Tbk \\
PGAS & Pelekomunikasi Indonesia (Persero) Tbk \\
PTBA & Thited Tractors Tbk \\
SMGR & Serusahaan Gas Negara (Persero) Tbk \\
TLKM & Uniliver Indonesia Tbk \\
UNVR & \\
\hline
\end{tabular}

\section{Gambar 1.}

Pengaruh EPS, ROE, ROA, ROS, ROI terhadap Return Saham dengan Size Sebagai Variabel Kontrol

Variabel Independen

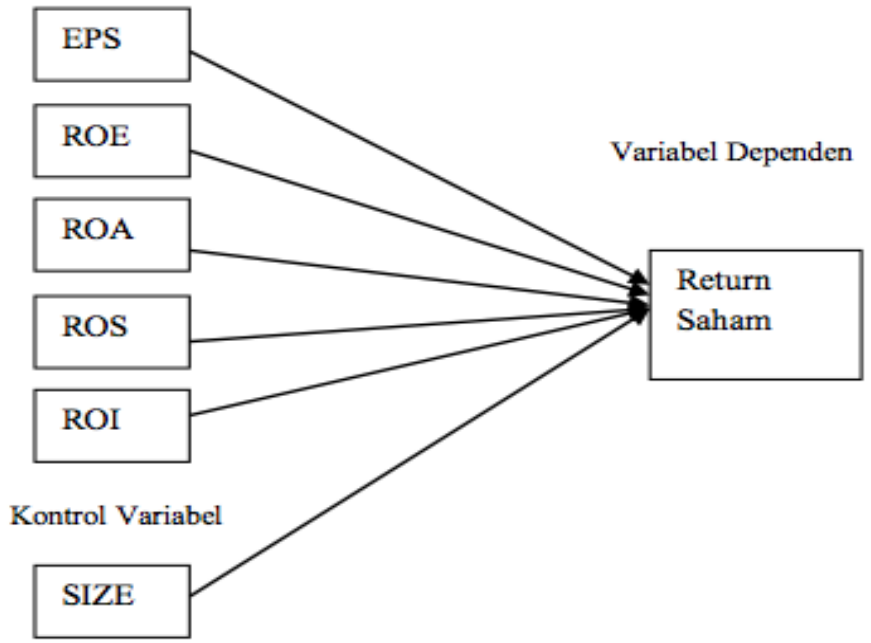


perusahaan (Ghadiri Abolfazi Moghaddam, Yonez, et al, 2015). Ukuran perusahaan sebagai variabel kontrol digunakan untuk mengontrol profitabilitas dan return saham.

\section{Metodologi Penelitian \\ Populasi dan Sampel}

Jenis data yang digunakan adalah data sekunder yang didapat dari laporan keuangan tahunan pada Indonesia Stock Exchange (IDX) pada perusahaan yang termasuk dalam Jakarta Islamic Index (JII) selama periode 2012-2016. Berikut kriteria penentuan sampel yang digunakan

Tabel 2.

Definisi dan Pengukuran Variabel

\begin{tabular}{llc}
\hline \multicolumn{1}{c|}{ Variable } & \multicolumn{1}{c}{ Definisi } & Formula Pengukuran \\
\hline Return Saham & $\begin{array}{l}\text { Return saham adalah return yang didapat } \\
\text { oleh pemegang saham yang telah melakukan } \\
\text { investasi pada sebuah perusahaan go-publik }\end{array}$ & R it = P(it) - P (it-1) \\
/ Pit-1
\end{tabular}

Return On Equity (ROE) adalah memandangny a sebagai produk marjin laba (penghasilan

Return on Equity (ROE) bersih dibagi pennjualan) dan perputaran ekuitas (penjualan dibagi dengan ekuitas ROE $=$ Laba setelah pemegang saham (Sharp, et al, 2006) pajak / Modal sendiri

Return on Asset (ROA) adalah rasio yang mengukur kemampuan perusahaan

Return on Asset (ROA) menghasilkan profit atau laba pada tingkat pendapatan, dan aset tertentu. (Sikarwar E Gupta, 2016)
ROA = Laba sebelum pajak dan bunga / Jumlah aset

Return on Sales (ROS)

Return on Sales (ROS) merupakan rasio profitabilitas (Pendapatan bersih / penjualan bersih)

ROS = Laba sebelum pajak / penjualan

Return on Investment (ROI) merupakan rasio Return on Investmen t (ROI) profitabilitas yang mengukur kemampuan perusahaan menggunakan dana perusahaan untuk kegiatan operasional (Munawir, 1195)

$$
\mathrm{ROI}=(\text { Total }
$$

Penjual-Investasi)/ Investasi x 100\%

Logaritma natural dari ase 
dalam penelitian ini : 1. Perusahaan yang termasuk dalam Jakarta Islamic Index (JII) berturut- turut selama tahun 20122016 , 2. Perusahaan yang menyampaikan laporan keuangan tahunan secara rutin dan memilki aspek data yang dibutuhkan dalam penelitian.

Berdasarkan kriteria sampel yang digunakan, berikut data sampel yang digunakan dalam pengolahan data penelitian perusahaan yang termasuk pada Jakarta Islamic Index (JII) periode 2012-2016.

\section{Analisis Regresi}

Analisis regresi bertujuan untuk melihat pengaruh dari variabel independen terhadap variabel dependen dengan ukuran perusahaan sebagai variabel kontrol :

$$
Y=\alpha+\beta 2 \mathrm{EPS}+\beta 3 \mathrm{ROE}+\beta 4 \mathrm{ROA}+\beta 5
$$

$\mathrm{ROS}+\beta 6 \mathrm{ROI}+\beta 7$ Size $+\mathrm{e}$

Regresi yang dilakukan dalam penelitian ini adalah menggunakan uji koefisien determinan, uji t dan uji f. Uji f digunakan untuk melihat pengaruh variabel independen terhadap variabel dependen secara simultan dengan size sebagai variabel kontrol. Sedangkan uji t digunakan untuk menganalisis pengaruh masing-masing variabel independen terhadap variabel dependen dengan size sebagai variabel kontrol.

\section{Hasil Analisis dan Pembahasan Hasil Analisis}

Berikut hasil statistik koefisien determinasi, dan uji $f$ pada pengearuh earning per share (EPS), return on equity (ROE), return on asset (ROA), return on sales (ROS), return on investment (ROI) dan size terhadap return saham.

Pengujian uji $t$ dalam pengaruh earning per share (EPS), return on equity (ROE), return on asset (ROA), return on sales (ROS), return on investment (ROI) dan size terhadap return saham menunjukkan hasil statistik sebagai berikut :

Variabel size pada hasil regresi menunjukkan bahwa size berpengaruh positif signifikan terhadap return saham, sehingga dapat digunakan untuk variabel kontrol. Hasil regresi statistik pada uji $t$ menunjukkan bahwa earning per share (EPS), return on asset (ROA), dan return on investment $(\mathrm{ROI})$ mempunyai pengaruh

Tabel 3

Hasil Koefisien Determinasi dan Uji F

\begin{tabular}{cc}
\hline Adjuster R Square & Probability \\
\hline 0.988 & 0.00 \\
\hline
\end{tabular}

Tabel 4

Hypothesis Testing Result

\begin{tabular}{ccc}
\hline & Coefficient & Probability \\
\hline constant & 0.620 & 0.00 \\
EPS & 0.442 & $0.00^{* *}$ \\
ROE & 0.011 & 0.753 \\
ROA & 0.545 & $0.00^{* *}$ \\
ROS & -0.002 & 0.912 \\
ROI & 0.395 & $0.00^{* *}$ \\
SIZE & 0.320 & 0.00 \\
\hline Keterangan: ** sig $<0.1$ &
\end{tabular}


yang positif dan signifikan terhadap return saham. Nilai signifikansi pada variabel EPS yaitu sebesar 0,00 dengan nilai koefisien regresi sebesar 0,442. Variabel ROA yang menunjukkan hasil bahwa ada pengaruh yang positif dan

signifikan terhadap return saham dengan nilai signifikansi 0,00 dan nilai koefisien regresi sebesar 0,545 . Nilai signifikansi pada variabel $\mathrm{ROI}$ terhadap return saham yaitu sebesar 0,00 dengan koefisien regresi sebesar 0,395. Hasil statistik juga menunjukkan variabel return on equity (ROE) mempunyai pengaruh yang positif terhadap return saham tetapi tidak signifikan, dilihat dari nilai signifikansi sebesar 0,753 dan koefisien regresi menunjukkan nilai sebesar 0,11 . Pada variabel return on sales (ROS) dalam hasil statistik menunjukkan pengaruh yang negatif namun tidak signifikan.

\section{Pembahasan}

investor pada Jakarta Islamic Index (JII) untuk pengambilan keputusan dalam berinvestasi. Peningkatan return on asset (ROA) direpresentasikan mampu meningkatkan return bagi investor, sehingga nilai ROA menjadi perhatian tersendiri bagi investor dalam menjalankan investasi. Besarnya nilai return on asset (ROA) menunjukkan bahwa sebuah perusahaan mampu mengatur aset dengan sedemikian rupa untuk mendapatkan laba perusahaan.

Rasio kedua yang disukai oleh investor yang digunakan sebagai pertimbangan untuk keputusan berinvestasi adalah rasio earning per share (EPS). Nilai earning per share (EPS) dilihat dapat menggambarkan bagaimana perusahaan dapat memberikan earning pada tiap lembar saham perusahan. Peningkatan nilai earning per share (EPS) akan menjadi sinyal positif untuk investor dalam pengambilan keputusan berinvestasi. Nilai earning per share (EPS) jelas memperlihatkan bahwa seorang investor akan mendapatkan besaran earning dalam setiap lembar investasinya. Sehingga hal ini menjadi salah satu fokus perhatian dalam mempertimbangkan saham yang akan diambil.

Selanjutnya rasio yang menjadi fokus investor dalam pengambilan keputusan investasi adalah return on investment (ROI) yang dijadikan sinyal positif sebuah perusahaan mampu memberikan return yang besar pula bagi investor. Nilai return on investment (ROI) menunjukkan sebuah efesiensi sebuah manajemen perusahaan. Analasis return on investment (ROI) dapat mengukur efesiensi modal, efesiensi produksi dan efesiensi dari penjualan. Kemampuan perusahaan dalam mengatur manajemen perusahaan, menjadi harapan bagi investor untuk menghasilkan laba dan return yang tinggi bagi investor. Sehingga nilai rasio $\mathrm{ROI}$ menjadi perhatian bagi investor dalam pengambilan keputusan investasinya.

Nilai return on equity (ROE) menunjukkan pengaruh yang positif namun tidak signifikan terhadap return saham. Investor tidak terlalu melihat pada nilai return on equity (ROE) untuk menilai sebuah saham yang termasuk dalam Jakarta Islamic Index (JII). Hal ini dimungkinkan karena investor melihat bahwa adanya return oon equity.

(ROE) ini tidak menjamin laba berdasarkan ekuitasnya. Nilai return on equity (ROE) yang meningkat tersebut tergantung pada ukuran perusahaan tertentu saja, sehingga perlu analisis lebih lagi dalam menentukan investasi.

\section{SIMPULAN}

Tujuan dari penelitian ini adalah untuk menganalisis pengaruh rasio profitabilitas terhadap return saham pada Jakarta Islamic Index (JII) periode tahun 2012-2016. Hasil penelitian berdasarkan pengolahan statistik menunjukkan bahwa rasio profitabilitas yang dapat mempengaruhi return saham pada saham-saham yang termasuk dalam Jakarta Islamic Index (JII) periode 2012-2016 adalah earning per share (EPS), return on asset (ROA), dan return on investment (ROI), dan variabel size atau ukuran perusahaan dapat 
digunakan sebagai kontrol perusahaan dalam pengaruhnya profitabilitas terhadap return saham. Dengan adanya hasil penelitin ini diharapkan perusahaan dapat memberikan perhatian lebih pada rasio-rasio yang menjadi fokus investor dalam menilai sebuah saham. Sehingga adanya nilai rasiorasio profitabilitas yang meningkat menjadi daya tarik investor untuk menginvestasikan dananya pada saham- saham syariah yang termasuk dalam Jakarta Islamic Index (JII). 


\section{DAFTAR PUSTAKA}

Arabsalehi, Mehdi dan Imam Mahmodi. 2012.

"The Quest for superior Financial Performance Measures"International Journal of Economics and Finance Vol.4,No.2.

Ismail, Issham. 2013. "Economic value added (EVA) versus traditional tools in predicting corporate performance in Malaysia" African Journal of Business ManagementVol. 7(18), pp. $1757-1764$

Madhavi Edan M S V Prasad. 2015.

"Assessing Corporate Performance with Measures of Value Added as Key Drivers of Shareholder Wealth: An

Empirical Study". The IUP Journal of Business Strategy, Vol. XII, No. 4.

Maditinos, Dimitrios I, "eljko $S$ " evic dan Nikolaos G Theriou. 2009. "Modelling traditional accounting and modern value-based performance measures to explain stock market returns in the Athens Stock Exchange (ASE)"Journal of Modelling in Management Vol. 4 No. 3.

Moghadam, Abolfazl Ghadiri, Yonez Gholami, Areezo Salarian, et al. 2015. "The Relationship Between EPS and CFO with Return on Shares in Compenies Listed in Tehran Stock Exchange". Internazional Journa of Academic Research in business and Social Sciences.

Palliam, Ralph. 2006. "Further evidence on the information content of economic value added"Accounting and FinanceVol. 5 No. 3, 2006pp. 204- 215. Sharpe William, Gordon J. Alexander, dan Jeffrey W Bailey. 2006.

Sikarwar, Ekta dan Vijay Kumar Gupta. 2016.

"Value creation of EVA and traditional accounting measures : Indian Evidence"International Journal of Productivity and Performance ManagementVol. 65 Iss 4 pp.

Sharpe William, Gordon J. Alexander, dan Jeffrey W Bailey. 2006. Investment.Edisi 6.Jilid 1.

Sharpe, W F., Alexander, Gordon J., et al.(2006).Investasi. Jilid 2.Jakarta.:PT.Ikrar Media Abadi.

Setiawan Edo, Rochmawati (2012),

Akuntabilitas, Jurnal penelitian dan pengembangan akuntansi, "Pengaruh informasi akuntansi terhadap return saham" Vol.6 No 2 Juli 2012

Sucipto.(2003). "Penilaian Kinerja Keuangan". Sumatera: Jurnal Digital Library Universitas Sumatera Utara.

Turvey, Calum G, Linda Lake Erna, Van Duren, David Sparling. 2000. "The Relationship Between Economic Value Added and the Stock Maerket Performance of Agribusiness Firms"Agribusiness, Vol. 16, No 4, 399-416.

Utama, S, 1997. Economic Value Added: Pengukuran dan Penciptaan NilaiPerusahaan. Manajemen Usahawan Indonesia.April, No. 4, TH XXVI, Hal.10-13.

Weston, J. Fred., dan Thomas E. Copeland, 1995, Manajemen Keuangan, Edisi 8.Jilid 1. Alihbahasa: Jaka Wasana dan Kirbrandoko. Gelora Aksara Pratama, Jakarta

Majid Jami, Mahdi Naqdi Bahar. 2016. "Analysis of Profitability to Evaluation of Performace of Indian" Journal of Current Research in Science . vol., S(1), 747-755, 2016.

Violeta Monica, Sorin Nicolae. 2011. "Business performance : between profitability, return and growth" 